\title{
A permanência da tradição na contemporaneidade: notas sobre Alexei Bueno
}

Tradition's permanence in contemporary literature: notes on Alexei Bueno

\author{
Francisco Diniz Teixeira* \\ Brunno Vinicius Gonçalves Vieira**
}

\begin{abstract}
RESUMO: O presente artigo é fruto de reflexões acerca da presença de elementos da tradição na poética de Alexei Bueno, poeta ativo desde os anos 1980. O texto apresentado se organiza em três partes: a inicial, em que se apresenta uma revisão da fortuna crítica acerca das percepções da crítica especializada sobre o resgate da tradição na poesia publicada nos últimos trinta anos; a segunda, em que se apresenta uma reflexão a respeito da fertilidade da tradição, com base na análise de uma ode de Horácio e outra de Ricardo Reis (Fernando Pessoa); a final, em que apresenta uma projeção das reflexões discutidas anteriormente a partir da leitura analítica de uma ode de Alexei Bueno.
\end{abstract}

PALAVRAS-CHAVE: ode, literatura comparada, literaturas clássicas

\begin{abstract}
This paper results from reflections on the presence of elements of tradition in the poetics of Alexei Bueno, a poet in activity since the early 1980s. The text is organized in three parts: at first, it presents a review of critical studies on specialized critics' perceptions and reactions to the rescue of tradition in the poetry published over the last thirty years; the second section, which dwells on the fertility of tradition, is based on analyses of odes by Horace and Ricardo Reis (Fernando Pessoa); such considerations are recollected and presented in the last part, based on the analytical reading of one of Alexei Bueno's odes.
\end{abstract}

KEYWORDS: ode, comparative literature, classical literature

Múltipla, oscilando entre a vanguarda, a tradição e a contradição, assim tem sido a poesia brasileira das últimas décadas.

A epígrafe acima, transcrita de um ensaio de Antônio Carlos Secchin (1996, p. 110), permite que se perceba como a crítica literária tem recebido a poesia brasileira publicada nos últimos trinta anos. Essa multiplicidade poética pode ser observada em diversas tendências, a exemplo de poetas como Francisco Alvim ou mesmo Ana Cristina César, que se mantêm mais apegados à tradição canonizada pela poesia modernista do princípio do século passado. Entretanto, poetas como Alexei Bueno e Bruno Tolentino, por outro lado, empreendem um resgate da tradição clássica.

\footnotetext{
${ }^{*}$ Doutorando na UNESP de Araraquara.

** Professor Assistente-Doutor do Curso de Letras (UNESP - Araraquara) e do Programa de Pós-Graduação em Estudos Literários.
} 
Assim, a multiplicidade que será discutida é um dos aspectos que a poesia contemporânea brasileira revela, ao lado de outras tendências, tais como a abolição ou não do verso, a projeção visual meramente acústica ou verbal e, dentre outras possibilidades, a crítica como um campo profuso e fértil de inquietações e investigações.

Neste texto, a princípio será feita uma recapitulação em duas etapas: primeiramente, analisaremos como a crítica percebe os contornos imprecisos e/ou dispersos da poesia contemporânea para que, posteriormente, se possa discutir e pensar o papel da tradição de forma isenta e objetiva. Cumpridas essas duas etapas, será examinado um poema de Alexei Bueno a partir da compilação feita de sua Poesia Reunida (2003), vis-à-vis ao que escreveram Horácio e Ricardo Reis, heterônimo de Fernando Pessoa, intertextos notáveis da poesia do autor carioca.

\section{Percepções da crítica acerca da poesia contemporânea}

Para que se possa entender a presença tanto do verso de forma fixa quanto do verso livre na(s) poética(s) singular(es) de diversos poetas que publicaram nos últimos trinta anos, tornase necessário fazer um rastreamento de como a crítica lida com esse fenômeno e como ela o explica. Para que seja possível realizar esse levantamento, os textos críticos de Antônio Carlos Secchin, Benedito Nunes, Iumna Maria Simon, Fábio Andrade e Ítalo Moriconi são de importante consideração, pois, além de apresentarem um panorama da produção poética atual, servem para indicar também poetas cuja produção pode ser considerada relevante.

Antônio Carlos Secchin (1996), em “Caminhos recentes da poesia brasileira”, indica a década de 1950 como marco inicial para que seja possível rastrear os movimentos norteadores da poesia mais recente feita no Brasil. A razão para a escolha desta época foi o surgimento do concretismo, movimento de vanguarda que pregava o fim da distinção entre conteúdo e forma. A esta vanguarda se seguiram a poesia práxis de Mário Chamie, cujo interesse abandona a pesquisa da linguagem empreendida pelos concretistas e se volta para a participação social, e o poema-processo, movimento liderado por Wlademir Dias Pino, que propôs, em suas versões mais radicais, abolir a palavra do poema, reduzindo-o a um jogo gráfico (SECCHIN, 1996, p. 97).

Secchin continua suas anotações, agregando ao rol destas correntes a poesia engajada da década de 1960 que está registrada nas antologias do Violão de rua e a produção dos poetas marginais e dos músicos da MPB surgidos nos festivais da década de 1960, como Caetano Veloso e Chico Buarque. Ele considera que esta produção se posiciona na esteira do 
Modernismo e ainda apresenta uma lista de poetas relevantes por sua qualidade estética, como Ivan Junqueira, Cora Coralina, Manoel de Barros e Gilberto Mendonça Teles, dentre outros.

Por outro lado, em “A recente poesia brasileira: expressão e forma” (2009), Benedito Nunes apresenta como ponto de partida do recorte histórico que fez, a presença de uma tradição moderna constituída pelas obras dos escritores que surgiram após 1922, como Drummond e Murilo Mendes. A esta se segue a antitradição da poesia concreta, nas décadas de 1950 e 1960. Nos anos 1970, quando a decepção com a cultura assume ares de reprodução do autoritarismo político, surge a geração transgressora dos poetas marginais (NUNES, 2009, p. 160).

Para Nunes, a partir da década de 1980, o que há em termos de orientação estética não é a busca do novo, mas sim “a propensão à glosa e à paródia, resultante do que podemos chamar de esfolhamento das tradições [...], a conversão de cânones, esvaziados de sua função normativa, em fontes livremente disponíveis com as quais [...] dialogam os poetas” (2009, p.167-168). Consoante a isso, pode-se entrever que o esfolhamento das tradições constitui a chave para que se apreenda a poética múltipla dos poetas surgidos após 1980.

Dessa forma, como facetas desse esfolhamento, Nunes apresenta a tematização reflexiva da poesia, a técnica do fragmento, o estilo neorretórico, a configuração epigramática e indica os principais cultores de cada faceta. O que se pode perceber a partir da leitura nunesiana é que o novo só se constitui como tal, se for algo proposto pelos poetas em termos de ruptura, tal como prezava o projeto estético de nossos primeiros modernistas. Por isso, na poesia publicada a partir da década de 1980, não há o que se possa detectar como novo/novidade, uma vez que não há ponto de ruptura em relação ao passado. Provavelmente, a impossibilidade de se propor ou de alcançar o novo esteja equiparada à multiplicidade de tendências observadas na produção literária surgida nesse período, ou dentro da obra de um mesmo poeta.

Por sua vez, Iumna Maria Simon ${ }^{1}$ (1999), em “Considerações sobre a poesia brasileira em fim de século”, apresenta um recorte e uma leitura sobre as tendências da produção recente

\footnotetext{
${ }^{1}$ Em artigo mais recente publicado na revista Piauí, "Condenados à tradição: o que fizeram com a poesia brasileira”, Iumna Maria Simon (2011), analisa dois fragmentos de entrevistas dos poetas Eucanaã Ferraz e Carlito Azevedo. A autora afirma em tom angustiado que a relação desses dois poetas com a tradição seria uma forma de "retradicionalização frívola”, uma vez que esta constitui uma fonte de “arquivo de formas (...) livre de oficialismo - um oficialismo sem burguesia e sem Estado, mas muito ativo e negociável no mercado de bens culturais (...). Um pluralismo facilitador de concessões inumeráveis (...)”. Para Simon, há uma falência do projeto estético dos poetas que mantêm uma relação ambígua com a tradição, particularmente a moderna, pois houve uma abdicação de um projeto de transformar a realidade, ou mesmo de modernizar o país. O abandono deste projeto se torna indício da angústia percebida no texto como um todo, e em particular nesta passagem: "A tradição se tornou um arquivo atemporal, ao qual recorre a produção poética para continuar proliferando em estado de indiferença em relação à atualidade e ao que fervilha dentro dela”.
} 
da poesia brasileira, aproximados aos de Secchin e de Nunes. Contudo, nesse recorte perpassando o Modernismo, o Concretismo e a poesia marginal -, percebe-se que sua leitura da poesia feita a partir da década de 1980 aponta duas tendências majoritárias. Por um lado, vêse uma retradicionalização inicial e, por outro, uma pulverização pluralizada de tendências, pois “quase todos os seus procedimentos e técnicas se tornaram anacronismos, isto é, recursos poéticos que prescindem da experiência e da própria poesia, reduzidos ao culto de gêneros, referências e alusões a si mesmos” (SIMON, 1999). Para a ensaísta, a poesia contemporânea que segue os rastros da retradicionalização não passa de exemplo de beletrismo e de preciosismo verbal.

Essas tendências mostram a carência de um anseio pelo novo. Entretanto, constata-se que o anseio daquele novo integrado pelos radicalismos de teor social (como no caso do Modernismo de início do século anterior, que se propôs a apresentar uma visão crítica do país e da identidade nacional a partir do projeto estético das vanguardas europeias), de teor formal (no caso do Concretismo, que apresentou um projeto estético de superação dos limites da forma artística), ou de teor expressivo (no caso dos poetas marginais, que abandonaram o paradigma concretista e promoveram uma reaproximação do projeto estético do primeiro Modernismo), tornou-se algo inócuo (Cf. SIMON, 1999).

Nesse sentido, a linguagem dos poetas que surgiram após a década de 1980 abdicou do novo e, na visão de Iumna, se conformou aos modelos pré-existentes, assumindo um “oficialismo desprovido de Estado e burguesia - e não é no mínimo estranho que o bandeirismo,

Como réplica ao artigo de Simon, o crítico Luis Dolhnikoff em "O paradigma nacional-popular da USP em literatura" publicado na revista Sibila, apresenta uma leitura que aponta sérios equívocos no artigo de Simon. Estes equívocos giram em torno da defesa do argumento central de que a poesia atual se apropria de modo parasitário da "tradição", e que estaria na base do conceito de "retradicionalização frívola" cunhado por Simon. Dolhnikoff aponta que, nas declarações de Eucanaã Ferraz e Carlito Azevedo, há uma incapacidade de lidar com o mundo contemporâneo. Tal incapacidade é dissimulada em uma adesão por (falta de) opção à tradição. Trata-se de um exercício de diálogo, pautado por um tom eclético, desprovido de senso crítico, uma vez que se abandonou o projeto de modernização do país através da arte, tão caro aos nossos primeiros modernistas. Isso já seria indício suficiente para que se entendesse que a condenação aludida no título do artigo de Iumna Simon não passaria de adesão voluntária. Esse quadro já havia sido diagnosticado por Haroldo de Campos em 1984, no ensaio "Poesia e Modernidade", presente em $O$ arco-íris branco. Esta adesão ao passado sem que se resguarde um viés crítico e modernizador é apontada por Simon em seu texto como um erro a ser contabilizado no conjunto do legado de Haroldo de Campus. Dolhnikoff se contrapõe à Simon e desfaz o equívoco, pois o "fracasso, a renúncia ou a resignação dos poetas contemporâneos não é afinal culpa de Haroldo de Campos”.

Em suma, a análise com embasamento sociológico que não adentra os aspectos linguísticos/formais do texto literário, não passa de exercício de péssima retórica, embebida em achismo, o que não contribui para uma visão objetiva e isenta do panorama amplo da poesia publicada nos últimos trinta anos. 
o drummondismo, o cabralismo, o concretismo, o leminskismo, etc., tenham se tornado griffes? ${ }^{2 ”}$ (SIMON, 1999, grifo da autora), isto é, a mera reprodução do passado.

Já Fábio Andrade (2010), em “A poesia brasileira atual” - investiga não só a produção crítica a respeito da poesia brasileira contemporânea, mas também a produção de alguns dos poetas que publicam a partir de 1980. Para Andrade, a palavra de ordem na poesia atual é a pluralidade e ele elenca algumas tentativas de apreensão da realidade poética múltipla, a começar pelos apontamentos de Manuel da Costa Pinto, Eucanaã Ferraz, Cláudio Daniel e Rodrigo Garcia Lopes. Contudo, Andrade aponta algumas falhas da leitura de Costa Pinto, como a parcialidade e a afinação com interesses que assumem matizes diversos de acordo com o projeto estético de cada poeta e cujo esboço se apresentará a seguir.

Andrade apresenta quatro tendências que caracterizariam a poesia contemporânea feita no Brasil, seus principais nomes e uma definição sucinta de cada uma delas:

1. Poesia Marginal, surgida como resposta direta ao clima opressivo do regime militar, buscando a espontaneidade e o retratismo do cotidiano político;

2. Poesia Visual, herdeira e continuadora de determinados procedimentos do concretismo, bem como de outras vanguardas;

3. Poesia de Renovação das formas tradicionais e do cotidiano, indicando obliquamente uma forte presença de poéticas como as de Drummond e Manuel Bandeira, mas em que se pode encontrar certo classicismo.

4. Poesia Hermética, acrescentando ao cânone brasileiro novas referências, poetas difíceis e de dicção singular, apresentando ainda grande parentesco com valores da alta modernidade (ANDRADE, 2010, p. 54).

Desse panorama, que não destoa do que Secchin, Nunes, Simon e Ítalo Moriconi também propõem, como se verá a seguir, pode-se entender que a preocupação principal desses críticos acerca do entendimento da poesia contemporânea é, de fato, a problemática do novo. O que o próprio Fábio Andrade comenta a respeito dos poetas da terceira tendência apresentada pode ser relacionado ao que ele fala de intertexto como "a função de regular a 'originalidade' literária. O caráter de novidade dessa poesia [...] se fixa [...] na sua constante renovação, numa atitude despida do fetiche da novidade” (ANDRADE, 2010, p. 68-69).

\footnotetext{
${ }^{2}$ No texto de Simon, o conceito de griffe estética está associado ao universo da moda, em que o estilo de um poeta antecessor constituiria uma série de elementos vintage, que seriam postos em circulação novamente na obra de um poeta mais jovem que o toma por modelo. Por isso, Simon fala em "bandeirismo", "drummondismo", "cabralismo", dentre outros, apropriações de projetos estéticos anteriores que fazem parte do cânone, mas que não se propõem à tarefa de empreender uma transformação social, ao contrário do que se observa em uma determinada etapa da obra de Drummond, João Cabral e Manuel Bandeira. Este tipo de preocupação ainda se encontra presente na obra mais recente de Simon, como se aludiu na nota anterior.
} 
Por fim, Ítalo Moriconi (1998), em "Pós-modernismo e volta do sublime na poesia brasileira”, comenta que o crítico desejoso de elaborar uma crônica do período situado entre 1980 e 1997 “não pode contar com os benefícios da distância irônica ou científica”, por isso ele demonstra “pouco apetite pelo panorama exaustivo” (MORICONI, 1998, p. 12). Isso ocorre porque o crítico elege como parte integrante de seu recorte historiográfico e/ou analítico, vertentes com as quais possua maior afinidade. E não se pode esquecer que a geração de críticos surgida na década de 1970 oscila entre duas tradições canônicas rivais: o paradigma do panteão modernista e o paradigma cabralino-concretista.

Moriconi estabelece seu recorte a partir da geração surgida na década de 70, à qual vincula como marca característica certa tendência dionisíaca, dada a presença do hedonismo, pela via da revalorização do corpo como elemento reafirmador de uma subjetividade anulada na poesia que seguia o esteio da tradição cabralino-concretista. Ele observa que na produção da geração surgida após 1980 há uma espécie de normalização pós-vanguardista, isto é, uma crescente preocupação com a funcionalidade e a natureza didática das manifestações artísticas (MORICONI, 1998, p. 13), algo que revela uma orientação de caráter fortemente pragmático, revelado pelo fato de muitos poetas terem migrado para a indústria do entretenimento, através da criação de letras de música, roteiros de atrações de televisão ou propagandas. E isto constitui uma nova tendência no resgate da fortuna crítica sobre o assunto, que não consta nos textos de Secchin, Nunes, Simon e Andrade.

Observa-se na geração da década de 80 que "sua relação com a linguagem e com a comunicação é de outra natureza”, isto é, “[...] a recuperação do valor propriamente literário da literatura. A poesia literária não se submete ao imaginário pop, embora dialogue o tempo todo com ele” (MORICONI, 1998, p. 18-19). A esta tendência pragmática, Moriconi acrescenta como faceta determinante uma volta ao tom discursivo da poesia, através do trabalho e da revalorização das formas clássicas e modernas do verso. Isso ocorreu sem deixar de lado a ambiguidade pós-moderna que marca a contemporaneidade e que “tem um sentido simultaneamente ‘progressista’ e ‘retrógrado’. Entretanto, esta oscilação, como se verá, representa a vitória da cultura iluminista sobre a contracultura” (MORICONI, 1998, p. 19), ou seja, uma ressublimação da poesia.

Constata-se que a crítica especializada, a partir do que se pôde observar na leitura dos textos de Secchin, Nunes, Simon, Andrade e Moriconi, alterna entre duas posições quanto à leitura e valoração da poesia publicada nos últimos anos. Por um lado, frente ao fenômeno do 
esfolhamento de tradições, isto é, da presença simultânea de diversas tendências canônicas, reapropriadas e reatualizadas pelos poetas, como matrizes criativas, há críticos que consideram pobre essa produção recente, justamente pelo fato dela não apresentar uma novidade constituída com base na ruptura em relação a modelos do passado. Por outro lado, há críticos que valorizam a multiplicidade de tendências, pois a novidade se dá, de fato, pela maneira como os jovens poetas se apropriam da tradição e criam o novo a partir do diálogo com o antigo, distante da imitação servil. A seguir, serão apresentadas algumas considerações sobre o papel da tradição e do anacronismo para que se entenda a permanência de ambos na poesia contemporânea.

Com base na síntese teórica apresentada acima, a par de diversas tendências como a abolição ou não do verso, a manutenção de uma tradição ligada ao modernismo do século XX, ou o trabalho com outros suportes, constata-se também um resgate da tradição que pode ser observado na poesia do carioca Alexei Bueno - ao retrabalhar a forma fixa e o ideário clássico -, que será objeto das considerações apresentadas no decorrer deste artigo.

\section{O papel da tradição}

Em relação aos estudos e à teorização sobre a tradição, não se recuará aqui até Aristóteles, pois suas ideias são de conhecimento amplo para os interessados nos estudos literários. A reflexão apresentada a seguir partirá do que pensam a respeito da tradição Octavio Paz, Hans Magnus Enzensberger, Célia Pedrosa, Gian Biagio Conte e Alessandro Barchiesi (estes dois últimos, - latinistas italianos e professores universitários na Itália e na Inglaterra).

Octavio Paz (1984) afirma que a modernidade literária se constituiu assentada naquilo que ele chama de "tradição de ruptura". Essa tradição se fundamenta não apenas na busca e valoração da novidade - por extensão, entendido como algo diferente -, mas na ruptura com o passado (imediato), na negação crítica de que o hoje seja fruto do ontem. Em outras palavras, trata-se da negação da unidade entre o passado e o presente, pois aquele pode assumir múltiplas facetas. Logo, o pilar essencial da tradição de ruptura é a consciência histórica da mudança que permeia nossa época. A mudança conduz o espírito da modernidade à procura do futuro, justamente por ser esse o tempo do "que ainda não é e que sempre está a ponto de ser” (PAZ, 1984, p. 34).

A par da tradição da ruptura Paz menciona também em relação à coexistência entre passado, presente e futuro, a função que o passado pode assumir, quando se investe de um 
aspecto ritual: “é um tempo imutável, impermeável às mudanças; não é o que passou uma vez, mas o que está passando sempre [...]” (PAZ, 1984, p. 26). Esse passado, presentificado pelo ritual, defende a sociedade dos efeitos e da possibilidade de mudança, tornando-se a norma e o modelo de perfeição a ser perseguido, porque intemporal ${ }^{3}$.

Paz denomina a tradição vinculada a esse passado tornado presente de "tradição da analogia”, embora ele nunca a aproxime criticamente da "tradição da ruptura” em Os Filhos do Barro, como bem lembra o crítico Silviano Santiago (1989) em suas reflexões acerca da permanência de um discurso firmado na tradição dentro dos escritos dos primeiros modernistas brasileiros. Nos termos de Octavio Paz, estes promoveram a instauração da tradição moderna, rompendo com o passado e negando-o como modelo de perfeição a ser seguido. Na verdade, a tradição da analogia está assentada, na visão de Paz, na “correspondência entre coisa e palavra” (SANTIAGO, 1989, p. 103) e o poeta se torna o fundador do universo e do conhecimento por nomear as coisas, instaurando a tradição da analogia, o que parece retomar a mimesis aristotélica.

Faz-se oportuno, para que se entenda melhor essa permanência do passado na contemporaneidade, paralelamente ao que se retomou de Octavio Paz, definir o que seria o anacronismo. Hans Magnus Enzensberger (2003) o define como a conjunção de assincronicidades, pois o que se observa é uma série de violações do curso do tempo que, para o teórico, são inevitáveis. Para explicar a pertinência do anacronismo, Enzensberger usa a metáfora da massa folhada para ilustrar que o tempo, assim como a massa, pode ser dobrado em diversas camadas, surgindo em pontos distantes uns dos outros de forma imprevisível; logo, o contato dessas camadas pode ocorrer de forma inesgotável em diversos momentos. Sobre o resultado desse processo, Enzensberger afirma o seguinte:

[...] Assim, o contato entre diferentes camadas do tempo não conduz ao retorno da mesma coisa, mas a uma interação que, todas as vezes, produz algo novo em ambos os lados. Nesse sentido, não é apenas o futuro que é imprevisível. O passado também está sujeito a mudança contínua, transformase sem cessar aos olhos de um observador que não possua uma visão geral de todo o sistema.

Quem julgar esse modelo óbvio considerará o anacronismo não uma fonte de irritação, mas um elemento essencial de um mundo mutável; em vez de negar o anacronismo, achará mais compensador contar com ele e torná-lo produtivo sempre que possível. (ENZENSBERGER, 2003, p. 20)

\footnotetext{
${ }^{3}$ Como adota João Alexandre Barbosa (2009, p. 36)
} 
Portanto, não se pode negar que o anacronismo esteja presente e que seja fonte de ideias brilhantes, num mundo marcado pela mutabilidade, como já bem observara Octavio Paz (1984). Este traço é perceptível nas obras de alguns poetas que publicaram nos últimos trinta anos no Brasil e parece ser o elemento constitutivo não só de suas obras, mas de suas poéticas, como é o caso de Alexei Bueno, de quem se tratará mais adiante no texto deste artigo. Por isso, não se pode concordar com a crítica de Simon, para quem a recorrência anacrônica em poetas recentes é traço de uma “condenação à tradição” ou de uma escrita poética beletrista, descompromissada.

Célia Pedrosa (2001), em um ensaio que examina os efeitos do anacronismo na poesia de Antonio Cicero e Rodrigo Garcia Lopes, faz um balanço de leituras críticas da poesia contemporânea a partir da dissolução da subjetividade lírica em diversas subjetividades e da presença de elementos anacrônicos, dos quais os poetas se apropriam como manancial da criação poética. Esse manancial rico permitiria ao poeta fundir o passado ao presente, mas sem obliterar as diferenças entre ambos na contemporaneidade (cf. PEDROSA, 2001, p. 13).

Para elucidar a importância dessa memória assentada no saber erudito, Célia Pedrosa (2001) recorre a Mário de Andrade, que já teorizara no começo do século passado a respeito da importância da erudição para o artista, pois através dela ele poderia adquirir “uma consciência técnica e ética por meio da qual [...] desbastaria seu tempo de fugazes aparências e definiria um rumo em meio à elasticidade desordenada de valores” (PEDROSA, 2001, p. 12). Nessa perspectiva, a subjetividade se constituiria em um mecanismo de resistência ao tempo do qual ela própria faz parte e no qual está inserida.

Sabendo-se que o anacronismo é um elemento inevitável, inescapável para que se pense criticamente a criação poética que ganha forma no que é publicado no país nos últimos 30 anos, e que se constitui como ferramenta interessante para a crítica dessa seara, seria interessante que se empreendesse uma aproximação ao que pensam Gian Biagio Conte e Alessandro Barchiesi, dois estudiosos ligados à cultura clássica. $\mathrm{O}$ arcabouço teorizado por ambos tem como ponto de partida a imitação e a alusão nos textos greco-romanos. Tais recursos muito produtivos naquele sistema literário podem ser relacionados ao que os poetas contemporâneos têm feito. Barchiesi e Conte afirmam o seguinte:

[...] convém de pronto admitir que a alusão literária - o escritor que cita um predecessor - é um fato de paixão e sentimento. Os poetas tendem a se apresentar como amantes da poesia que leram e de que se recordam. Recordarse de um modelo, no sentido de citá-lo, serve para reproduzir na escrita a 
paixão, o apelo, produzidos pela leitura. O escritor, graças à arte alusiva, apresenta-se como leitor que ama certos textos (ou que por eles prova uma paixão qualquer, ainda que fosse ambivalente ou hostil). Não nos ocultemos, porém, que nessa paixão pode haver uma conveniência: e não somente porque assim fazendo o poeta se apresenta sob o sinal reassegurador de uma tradição e se auto-legitima (CONTE, G. B; BARCHIESI, A., 2010, p. 87).

Pode-se perceber que a tônica da intertextualidade como chave de leitura para a poesia latina em relação à precedente feita em Grécia não pode ser esquecida. Não se lê Virgílio ou Horácio apenas buscando em seus textos uma originalidade - desvinculada de um diálogo permanente com a tradição - de temática ou de forma, como se buscaria na leitura de Gonçalves Dias, Álvares de Azevedo e José de Alencar. A ilusão de originalidade, surgida no século XIX, de acordo com o rastreamento que Antonio Candido fez a respeito da produção romântica em O romantismo no Brasil, servia como instrumento de afirmação de uma identidade nacional por meio da literatura.

Na verdade, lê-se Virgílio ou Horácio para apreender a maneira como eles tomam de empréstimo aquilo que fosse mais interessante aos seus predecessores e como eles retrabalhavam esses elementos, fazendo com que eles ganhassem novos sentidos em seus textos. Essa observação frutífera para os estudos filológicos pode ser comprovada na leitura comparada de duas odes ligadas à lírica simpótica, respaldado no que diz Achcar a respeito do topos do carpe diem, ponto de intertexto entre os poemas selecionados:

[...] O modelo de um gênero parece estabelecido, e não é fenômeno desconhecido a transformação de topos em genos. Podemos dar-lhe o nome de carpe diem porque o teor deliberativo [...] deslocou-se para a exortação, não épica, a aderir ao “dia”. [...]

O que Cairns chama os "elementos primários” de um gênero são, aqui, todos congeniais à lírica simpótica: o sujeito dialogante (I. o enunciador), seu interlocutor (II. O enunciatário), a exortação (III. o enunciado de orientação conativa). (ACHCAR, 1994, p. 70-71)

Tendo em vista o que se retomou a respeito do processo de intertextualidade estabelecido na releitura por poetas de épocas diferentes de um mesmo topos, a partir deste momento passaremos à análise de três odes que desenvolvem a tópica do carpe diem. Para tanto, foram selecionados textos de Horácio, poeta romano do século I a.C., Ricardo Reis, heterônimo de Fernando Pessoa, e do poeta carioca Alexei Bueno.

A primeira ode que será apresentada se encontra no fecho do Livro I, exatamente o poema 38 das Odes de Horácio (2004, p. 94), seguida de uma tradução nossa: 
Pērsǐcōs

dīsplǐcēnt

mîttě sēră mŏrētūr.

$\begin{array}{cccc}\begin{array}{c}\text { òdī, } \\ \text { nēxāe }\end{array} & \begin{array}{c}\text { pǔĕr, } \\ \text { phĭly̆rā }\end{array} & \begin{array}{c}\text { āppărătūs, } \\ \text { cŏrŏnāe, }\end{array} \\ \text { sēctārī, } & \text { rŏsă } & \text { quō } & \text { lŏcŏrūm }\end{array}$

Sīmplīcī sēdǔlūs

dēděcēt uītě bỉbēntēm.

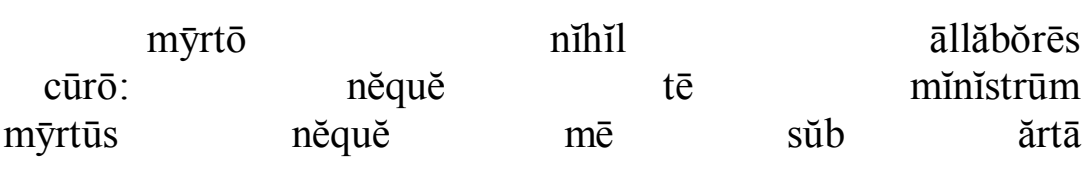

Garoto, odeio parâmetros pérsicos, Coroas cheias de atavios me irritam, Manda buscar uma rosa de um lugar Em que morra tardia.

De que nada à singela murta ajuntes Atento cuido: a murta a ti não presta escanção, nem a mim que estou bebendo Sob uma estreita vide.

Como bem anotam Nisbet e Hubard (2001, p. 421), essa ode horaciana endereçada a um escravo, uma espécie de copeiro, era um artifício comum e natural na lírica de simpósio grega e no epigrama ${ }^{4}$. Ambos citam como predecessores de Horácio, por terem tratado do mesmo assunto, Anacreonte, Pseudo-Aristóteles, o poeta cômico Efipo, Antífanes, um dístico de Filodemos e um epigrama de Niceneto, dentre os poetas gregos, sem esquecer que Catulo e Marcial também trabalharam essa temática em solo romano.

Para os leitores acostumados à busca incessante pelo novo, entendido como inédito, a leitura da ode horaciana deve ser frustrante, tendo-se em vista o rol de antecessores que trabalharam o mesmo tema. A tradução apresentada tentou reproduzir o tom despojado do original em latim do eu rejeitando os adornos ofertados para si e para o escravo no ambiente do simpósio. A escolha das palavras, assim como a sua disposição na estrofe sáfica, formada por três hendecassílabos sáficos, seguidos de um verso adônico, mais curto, são indício de um ideal de simplicidade que alia forma e conteúdo.

O poema se inicia com a imagem destacada do sintagma persicos apparatus ("os parâmetros pérsicos”) - que cercam o puer, destinatário das ordens apresentadas nesta estrofe -, objetos que o eu lírico rejeita, pois ele não se sente à vontade com o luxo oriental, que

\footnotetext{
${ }^{4}$ No original: "was a common and natural device in Greek sympotic lyric and epigram". (NISBET; HUBARD, 2001, p. 421).
} 
metonimicamente se refere à Pérsia, reino de opulência, censurado desde os gregos. Esta imagem, assim como aquela que aparece no verso dois, nexae philyra coronae ("coroas atadas com um tipo de fibra da Tília”), reforçam a objeção que o eu lírico tem de objetos suntuosos, pois essas coroas o irritam e são o que ele não deseja, como especificam os verbos disfóricos odi e displicent.

A estrofe termina com a última ordem apresentada ao jovem, o escravo responsável pela adega da casa, de que ele mande buscar uma rosa sera moretur ("uma rosa de um lugar que morra tardia”) e se deve ao fato de que na Itália as rosas florescem da primavera até o início do verão. Aqui, vê-se configurado um dos símbolos do carpe diem, tópica que prega que o tempo presente deve ser aproveitado ao máximo e que foi retomada em diversos momentos na história da lírica ocidental e também na de língua portuguesa, como já pontuou Francisco Achcar (1994, p. 87 ss.) em Lírica e lugar comum.

A segunda estrofe se abre com a imagem centrada em simplici myrto ("singela murta"), que o eu lírico pede ao jovem que não manuseie, pois, como ele afirma no sexto verso, sedulus curo (“atento cuido”). A murta é uma planta comum, rasteira, que aparece nos simpósios, entrelaçada a outras na forma de uma grinalda usada pelos simposiastas. Nisbet e Hubard (2001, p. 425) anotam que, de acordo com Filonides, dizia-se que a coroa de murta dissipava os vapores do vinho que subiam à cabeça do conviva. A opção pela murta, que também é um elemento associado ao culto de Vênus, assim como a philyra e as rosas que são rejeitadas pelo eu, marcaria uma escolha pela simplicidade, pelo gênero baixo (humilis, “chão”).

O segundo hemistíquio do verso seis e seu prolongamento sintático nos versos sete e oito marcam o fecho da estrofe e do poema. Neste sintagma, a figura do jovem escravo é retomada na palavra ministrum (“escanção”), um predicativo do pronome te no par em paralelismo métrico e sintático neque te (“nem a ti”) do verso 6 e neque me ("nem a mim”) do verso sete. O que liga esses dois sintagmas em paralelismo é o sujeito desse período, detectado no sintagma dedecet myrtus (“a murta presta ou convém”), que assume um sentido negativo por conta da negação neque que aparece duas vezes nessa estrofe, colocando em um mesmo nível baixo o "garoto" e o eu lírico.

O sintagma que fecha o poema sub arta uite bibentem ("que estou bebendo/sob uma estreita vide”), em paralelo com o que fecha a primeira estrofe rosa sera moretur ((“uma rosa de um lugar que morra tardia”) reforça novamente a tópica do carpe diem. Não convém ao eu (e nem ao escravo) o cuidado da murta, pois o que ele deseja é apenas aproveitar o tempo 
bebendo. O poema trabalha com duas tópicas associadas: de um lado, a da simplicidade presente nos versos um, dois, cinco, seis e parte do sete, representada pela aurea mediocritas, construída num estilo humilde observável na modulação do discurso e pela escolha da murta e, de outro, a tópica associada ao carpe diem verificável na presença das rosas serôdias e no desejo de beber.

Pode-se agora comparar à ode horaciana esta de Fernando Pessoa, que consta nas Odes de Ricardo Reis, a ode XVII do Livro I:

Não queiras, Lídia, edificar no spaço

Que figuras futuro, ou prometer-te

Amanhã. Cumpre-te hoje, não sperando.

Tu mesma és tua vida.

Não te destines, que não és futura.

Quem sabe se, entre a taça que esvazias,

E ela de novo enchida, não te a sorte Interpõe o abismo?

(Pessoa, 2007, p. 20)

Aparentemente, a ode de Ricardo Reis, que não deveria ter nada similar à ode de Horácio, apresenta, numa leitura mais atenta, inúmeras semelhanças. Este se dirigia a um escravo para rejeitar o luxo oriental, não condizente com seu ideal de vida simples. Aqui, vê-se o eu dirigindo-se a Lídia, sua amada na mesma situação degustadora do eu lírico da ode I, 38, e lhe recomendando que não confie no amanhã, tal qual Horácio (2004, p. 44) já advertia no poema 11 do mesmo Livro I: “cārpě dǐèm, quām münümūm crēeŭlă pōstěrō”, "colhe o dia, confiante minimamente no dia de amanhã”.

A ode de Pessoa é vazada também na estrofe sáfica, cultivada em língua portuguesa com três versos decassílabos seguidos de um hexassílabo. Mas a similaridade entre as duas odes não reside apenas na estrutura formal empregada em ambas. A primeira estrofe se abre com uma imagem desenvolvida ao longo dos versos e se articula em torno de uma admoestação do eu lírico endereçada à amada, contida no sintagma “Não queiras”. O período desenvolvido até o fim do terceiro verso traz um reforço da admoestação do primeiro verso: “edificar no spaço/Que figuras futuro ou prometer-te/Amanhã. Cumpre-te hoje não sperando.”.

A imagem centrada nesse período se refere a não projetar nada que se afaste da concretude da realidade e do tempo presente, pois na visão do eu lírico, a preocupação com o amanhã só traria sofrimentos e estaria condenada no sintagma “não sperando”. Lembramos que 
esse verbo etimologicamente provém do substantivo spes, que em latim significa justamente “esperança”.

Temos um diálogo projetado entre os dois poetas em torno da tópica do carpe diem, que em Horácio se articula na primeira estrofe em torno da imagem da rosa, símbolo da brevidade da vida e, em Ricardo Reis, em torno da imagem que se apresenta no último verso: "Tu mesma és tua vida.”. A vida humana pode ser representada metaforicamente na figura da rosa, pois ambas são breves, logo, a vida de Lídia é equivalente à rosa.

Há um paralelo na segunda estrofe da ode de Pessoa com a segunda do poema de Horácio. A ode pessoana apresenta a repetição do advérbio negativo “não” (equivalente a neque no poema latino), duas vezes no quinto verso e que já havia aparecido na primeira estrofe. Nesse verso, a conjunção está ligada ao verbo “destines” e à locução verbal “és futura”, esta última uma oração explicativa ligada ao verbo da primeira oração.

As imagens que se apresentam entre o sexto e o oitavo versos referentes à taça de vinho que oscila entre vazia e cheia, graças à diligência de Lídia (uma retomada da imagem presente em Horácio do ambiente de simpósio) e da morte - presente na ideia da sorte que interpõe o abismo, isto é, o desaparecimento da vida - reforçam em Reis o sentimento de aproveitar o momento presente e fruir o instante com o vinho, pois o tempo segue sua marcha inexorável, o que confirma a filiação dessa ode à tópica do carpe diem.

Além da similaridade temática, pode-se notar também a filiação de Reis a Horácio no nível sintático e fônico: o primeiro verso nas duas odes tem no hemistíquio o destinatário de cada eu lírico marcado pelo vocativo, o que faz puer no poema de Horácio equivaler a "Lídia” no de Ricardo Reis, numa relação de paralelismo.

Outro exemplo de paralelismo sintático poderia ser observado na posição das palavras rosa em Horácio e "hoje” em Reis, que sintetizam a ideia da brevidade da vida no terceiro verso de cada poema, assim como os sintagmas neque me sub arta (nem a mim sob estreita) e "não te a sorte” dos sétimos versos, que se constroem a partir de semelhante colocação pronominal.

O paralelismo fônico pode ser notado a partir da presença da aliteração dos fonemas “p”, “r” "t” e “c” (com a variante “q” na ode de Ricardo Reis), em ambos os textos, assim como as assonâncias (a exceção do “u” em Ricardo Reis), o que reforça a similaridade formal observada e a filiação do texto de Fernando Pessoa à poética que provém de Horácio.

Destacadas estas similaridades, não se pode negar que Fernando Pessoa tenha imitado Horácio, mas a imitação - um processo de transmetrização, isto é, uma transposição métrica, e 
de transestilização ${ }^{5}$, ou seja, uma reescritura estilística, como pensa Genette (1982, p.254-257) em Palimpsests - que ele empreende não se resumiu a mera cópia, pois, na verdade, o que os apontamentos feitos a partir das duas odes permitem que se vislumbre, é a apropriação por meio da alusão, chave de leitura que Conte e Barchiesi (2010, p. 87) defendem para a leitura de textos clássicos. A aplicação desta chave de leitura permite que se constate a presença de uma novidade no diálogo que Pessoa empreende ao se apropriar de Horácio, combinando as odes I, 11 e I, 38.

Essa leitura reforça a discussão que Célia Pedrosa faz a partir do resgate de Mário de Andrade, segundo a qual a erudição pode ser fonte de uma consciência ética e estética para o artista. Tal constatação comprova o pensamento de Paz em relação à permanência da tradição da analogia e o de Enzensberger em relação à presença do anacronismo como manancial a que os poetas podem recorrer. Nesse sentido, a erudição constitui matriz rica de material para a criação poética, como se mostrou acima nas notas sobre Fernando Pessoa em relação a Horácio.

\section{Um estudo de caso: Alexei Bueno e a tradição}

O poeta carioca Alexei Bueno, que produz desde o início da década de 1980, ilustra o segmento do “resgate do sublime”, que tanto Célia Pedrosa, quanto Ítalo Moriconi e Fábio Andrade apontam em nossa poesia contemporânea. Bueno trabalha com as formas fixas de forma magistral, mas não somente com elas, pois nas Odes de A via estreita, de 1995, pode-se constatar a presença do longo verso livre, conquista de nosso primeiro Modernismo.

A princípio, se poderia ler esse resgate das formas tradicionais como pretexto para um beletrismo e um preciosismo verbais descompromissados com a época presente, tal qual pensa Iumna Maria Simon, mas não parece ser esse o caso. Examine-se como exemplo uma ode que se encontra nos Poemas gregos ${ }^{6}$, de 1984 (BUENO, 2003, p. 184):

Por que, Dionisos, te enches do teu vinho

Se nada pode a morte contra ti,

E o tempo não te arranha mais do que uma

Formiga a uma montanha?

Por que bêbado vives, se és eterno,

E conheces que o vinho é mais precioso

\footnotetext{
5 Traduções nossas.

${ }^{6}$ Aqui se farão referências aos livros de Alexei que estão na edição da Poesia Reunida, publicada em 2003.
} 
Para os que sabem quão secos um dia, Só pó, serão na estrada?

Não te compreendo, pois, senhor da vinha,

A ebriedade! Ou será que há um tédio

Enorme em não morrer? Ou sóbrio sentes

Que tombarás também?

No poema acima, constata-se - dada a sua configuração em estrofes com três versos decassílabos heróicos (Por | que, | Dio | ni | sos, | te en | ches | do | teu | vi | nho / Se | na | da | po | de | a mor $\mid$ te $\mid$ con $\mid$ tra $\mid$ ti / E o $\mid$ tem | po | não | te ar | ra | nha | mais | do | que u | ma), seguidos de um hexassílabo (For $\mid$ mi $\mid$ ga a u $\mid$ ma $\mid$ mon | ta $\mid$ nha?) -, que se trata de uma ode de tom classicizante, embora o poeta não a tenha nomeado (e classificado) como exemplar desse gênero.

A primeira estrofe é aberta com a imagem de Dioniso (relembrado na forma de nominativo grega, transliterada em caracteres latinos “Dionisos”), deus do vinho, questionado pelo eu lírico por se fartar do próprio vinho. Não se pode esquecer que na Antiguidade o vinho associado ao culto de Dioniso possuía uma potência libertadora de estados da mente humana e dos limites físicos, algo marcado no mito dionisíaco pelo cortejo das Bacantes, que viviam em transe báquico. Logo, ao se embebedar, tal como questiona o eu lírico, Dioniso assume um comportamento tipicamente humano.

A isso, segue-se no segundo verso a imagem centrada na ideia da morte, que é impotente contra um imortal, somada no verso seguinte à ideia do tempo que não é capaz de promover nele transformações, como faria num mortal. O terceiro e o quarto versos emparelham uma comparação entre a formiga e o tempo. Este é incapaz de ferir um deus e aquela, uma montanha. Assim, a questão apresentada no primeiro verso, tal como as imagens subsequentes em tom prosaico $^{7}$, se justificam.

O texto construído com interrogativas diretas demonstra certa descrença (que, provavelmente, de acordo com a resposta do deus, se confirmaria ou não) do eu na divindade, tratada por “tu”, pronome que sinaliza uma maior proximidade, ao contrário do esperado "vós”, que mostraria certa reverência do eu para com o divino. A proximidade entre Dioniso e o eu,

\footnotetext{
${ }^{7}$ Cf. MORICONI, 1998, p. 23: “Em Alexei, o sublime é tema, mas a linguagem poética mantém-se dessublimada
} $[\ldots] "$. 
construída num tom prosaico, marca a fuga - por parte do poeta - de uma linguagem que se esperaria sublime, especialmente na sintaxe.

Na segunda estrofe, a imagem apresentada no primeiro verso é retomada agora no quinto num tom questionador que se estende até o oitavo verso. Qual a necessidade de Dioniso viver bêbado, uma vez que ele é eterno e a sua dádiva é mais útil para os mortais que "serão pó na estrada”? A ideia apresentada na primeira estrofe é retomada e intensificada, pois Dioniso não poderia ser angustiado pela morte como qualquer ser humano e, da mesma forma, o vinho não o libertaria (ele próprio que em latim era denominado Líber, ou seja, “livre”). Esse quadro apresentado pelo questionamento do eu permitiria inferir que Dioniso, ao assumir-se entediado pela eternidade, talvez buscasse adquirir uma "humanidade" que não condiz com sua condição divina. Por meio de tal conduta, Dioniso seria capaz de escapar ao tédio eterno.

Na última estrofe, o eu lírico reforça a indagação apresentada a Dioniso por conta de sua ebriedade, com duas novas questões. Na primeira, o eu lírico relaciona a eternidade vivenciada por Dioniso ao tédio, pois aquela seria a causa deste. Na segunda, questiona se Dioniso sentiria que poderia morrer se ficasse sóbrio, finalizando a ode. Nota-se que o eu lírico, num tom descrente, mas também baixo como o de Horácio e o de Pessoa, ironiza cinicamente Dioniso, trazendo-o para o mesmo nível de um ser humano, enquanto passível de sofrer as vicissitudes do tempo que, a propósito, é o assunto da ode.

Estas questões lembram aquelas que Horácio faz na ode 25 do livro III: Quo me, Bacche, rapis tui/plenum? Quae nemora aut quos agor in specus/uelox mente noua? Uma possibilidade de tradução livre em vernáculo poderia ser: "Baco, para onde me levas de ti/cheio? Sou impelido a quais bosques ou a quais cavernas/, rápido, em gênio novo?’

Para Horácio, questionar Baco, que o possuía, significa questionar que experiências o transe báquico despertaria no poeta, assumindo a inspiração dionisíaca como fonte do gênio poético, um gênio poético livre, assim como as mênades, seguidoras do cortejo do deus nas montanhas.

Porém, observa-se na ode de Alexei uma postura desencantada do eu lírico, típica de nosso próprio tempo, apesar do equilíbrio formal. Poder-se-ia dizer que essa postura, calcada numa linguagem dessublimada, isto é, baixa, nega, por descrença, a natureza divina e transcendente de Dioniso, materializada no vinho consagrado à sua potência, marcando um afastamento em relação a Horácio. 
Notam-se algumas similaridades entre essa ode de Alexei e as odes de Horácio e Fernando Pessoa analisadas anteriormente. Tal como preconiza Achcar (1994, p. 70-102.), um traço que une os três poemas é o de se tratar de uma ode de simpósio, algo bem evidente pelo jogo de alusão que Fernando Pessoa estabelece com Horácio, uma vez que essa foi a forma escolhida pelo poeta luso para reler a tradição. Entretanto, a ode de Alexei está centrada numa recusatio, como se pode inferir a partir dos questionamentos que o eu lírico dirige ao deus.

As três odes se articulam em torno do diálogo de um eu e seu interlocutor em torno da situação simpótica. No caso de Horácio, o diálogo se estabelece entre o eu e o puer, escravo responsável por servir o vinho, uma vez que se reservava aos escravos a execução de tarefas manuais. No caso de Fernando Pessoa, o diálogo se deu entre o eu e Lídia, sua amante que tinha a mesma função que o escravo horaciano em relação ao vinho. E, finalmente, no caso de Alexei, esta relação é observável na interlocução entre o eu e Dioniso, que é questionado pelo eu em relação ao uso próprio que faz do vinho (que perpassa os três poemas), sem necessidade, na opinião do eu.

O vinho que perpassa as três odes é um dos elementos associados ao carpe diem em Horácio, em função de sua fruição despreocupada, assim como a rosa, símbolo da fugacidade do tempo e da vida e a coroa de murta, por sua vez, simboliza a simplicidade pretendida pelo eu. Em Ricardo Reis, o vinho aparece como elemento do carpe diem, devido ao jogo de alusão estabelecido com Horácio, simbolizando a vida que deve ser fruída em cada momento, sem uma preocupação angustiante com o futuro, fonte de tédio para o eu.

Em Alexei, pelo contrário, o vinho é negado como elemento marcador da fruição do instante, uma vez que se encontra em questão a negação do carpe diem. Nesse último caso, tal negação só se torna possível, pois o eu lírico questiona em Dioniso, com um tom desencantado, o uso que o deus faz do vinho. Tal questionamento tem origem no fato de Dioniso ser imortal e não ter necessidade de alterar seu estado de consciência para fugir de angústias geradas pela passagem do tempo, ao contrário dos mortais. A ideia de tédio que há em Ricardo Reis ligada à angústia relacionada ao futuro aqui se encontra associada à angústia gerada no deus, pois este se percebe preso a um presente contínuo em função de sua imortalidade.

Logo, nesse poema de Alexei, há a retomada da tradição clássica, mas quando o eu questiona a ebriedade eterna do deus, pode-se antever uma subjetividade desencantada, típica dos poetas que publicaram nos últimos 30 anos, em especial naqueles que não adotaram a retradicionalização como esteio de sua criação poética. Essa subjetividade está na base do 
diálogo empreendido com a tradição, que se constitui na negação da tópica carpe diem, dada a ironia que se percebe subjacente ao tom empregado pelo eu lírico. Por isso, discorda-se do que pensa Alexandre de Melo Andrade (2010) para quem:

A ironia presente no texto desvela uma ruptura entre o finito e o infinito, entre a brevidade e a eternidade. Fundamentada no Romantismo, a ironia moderna arranha os princípios estabelecidos pelos princípios clássicos, destruindo a ordem estabelecida no macrocosmo para fazer sangrar o caos instituído pelo microcosmo. A poética de Alexei representa (...) a ironia romântica, que nele se realiza por meio da reabsorção das mitologias clássicas, suplantando-as ao tempo histórico.

Na verdade, essa ironia que reabsorve o mito, suplantando-o no tempo histórico, não é invenção do Romantismo, pois ela já existia na Antiguidade, como bem demonstra Luciano de Samósata nos Diálogos dos mortos, através do olhar cínico do espectro do filósofo Menipo, que atormenta os mortos no Hades como nesta passagem:

\section{Menipo e Hermes}

Menipo

E aí, Hermes? Onde estão os belos ou as belas? Sirva-me de guia, pois sou recémchegado!

\section{Hermes}

Não tenho tempo, Menipo. Em todo caso, dê uma olhada naquela direção, à direita, lá onde está o Jacinto, o Narciso, Nireu, Aquiles, Tiro, Helena, Leda, em suma, todas as beldades de antigamente.

Menipo

Só estou vendo ossos e crânios desnudos das carnes, praticamente iguais.

\section{Hermes}

Mas esses ossos que você parece desprezar são exatamente o que todos os poetas admiram!

Menipo

Ainda assim, aponte-me Helena. Por mim mesmo eu não poderia identificá-la!

Hermes

A Helena é esse crânio aí!

Menipo

Então, foi por essa coisa que se equiparam mil navios, vindos de todas as regiões da Hélade? Foi por ela que sucumbiram tantos gregos e bárbaros, e que tantas 
cidades foram devastadas?

Hermes

Mas você não viu essa mulher quando era viva, Menipo! Até você teria dito que era irrepreensível

"por uma tal mulher suportar dores tanto tempo".

(...) (1996, p.135-137.)

Logo, não é de estranhar que a ironia que Alexei emprega para humanizar Dioniso, questionando sua divindade, não se aproxime da ironia romântica, mas sim da ironia cínica, que a Antiguidade legou à posteridade. E pode-se comprovar essa mesma ironia em funcionamento quando Menipo questiona Hermes sobre o valor dos esforços dos gregos que tombaram em Troia por Helena, que agora, no Hades, não passa de um crânio desnudo, assim como todos os outros mortos.

Após a leitura da ode de Alexei Bueno e das observações feitas, seria interessante ressaltar, a propósito da ode do poeta carioca, o que Fábio Andrade (2010, p. 77) afirma: “[...] O espectro classicista [...] não esgota a dicção de uma produção que além de um profundo rigor formal [...] encontra lugar para o epos, para o verso livre e para a inquietação metafísica...”. Esta pode ser uma chave de leitura para que se compreenda a poética particular de Alexei Bueno, pois ele une a expressão formal tradicional ao verso livre.

Antonio Carlos Secchin, ao observar um sentido trágico na poesia de Alexei crê que “a visada de Alexei é trágica, oriunda de um mundo esquecido pelos deuses e assolado em demasia pelo sub-humano: a poesia mora e vigora nesse intervalo” (in ANDRADE, 2010, p. 77), e nos oferece uma possibilidade para explicar o desencanto constatado no poema transcrito acima, devido à consciência do poeta de que ele escreve num entrelugar e o resgate da tradição seja, talvez, a única forma que tenha de se opor ao caos contemporâneo.

Frente ao que se expôs até o presente momento, não se pode aceitar como uma possibilidade para entender a multiplicidade da poesia publicada atualmente - aludida na epígrafe inicial - a de que ela seja o reflexo de um supercânone. Este conceito foi proposto por Henrique Cairus (2011, p. 135) nos seguintes termos: “[...] O supercânone [...] paira sobre o cânone, dando-lhe consistência em forma e conteúdo, por anuência ou negação. É [...] o cânone do cânone, e também esse é um - mas não o único - aspecto do clássico que o faz clássico”.

Pelo contrário, na verdade, o resgate de formas e/ou temas tradicionais parece ser fruto daquilo que João Alexandre Barbosa (2009) chama de as duas ilusões da modernidade: ubiquidade e intemporalidade. Para Barbosa (2009, p. 36): “o poeta moderno, por força do 
movimento básico tradição/tradução, sabe que a sua linguagem não é senão um instante individual dos tempos da linguagem”. Logo, para o poeta moderno, o poema em si se constitui como o espaço de materialização do seu trabalho com a linguagem, a materialização de um instante dentre todos os instantes possíveis em que ele se pode inserir, pois no processo se discute a viabilidade tanto do seu ofício quanto dos objetos que cria.

\section{Referências bibliográficas}

ACHCAR, F. Lírica e Lugar-comum: Alguns temas de Horácio e sua presença em português. São Paulo: Edusp, 1994.

ANDRADE, A. M. Os deuses se tornam humanos: a poesia de Alexei Bueno. Texto Poético, Vol. 8, 2010, $1^{\circ}$ semestre. Disponível em: <http://www.textopoetico.com.br/index.php?option=com_content\&view=article\&id=94\&Ite $\underline{\text { mid }=30>}$. Acesso em: 06 Jul. 2013

ANDRADE, F. A poesia brasileira atual. In: . A transparência impossível: hermetismo e poesia brasileira. Recife: Bagaço, 2010.

BARBOSA, J. A. As ilusões da modernidade. São Paulo: Perspectiva, 2009.

BUENO, A. Poesia reunida. Rio de Janeiro: Nova Fronteira, 2003.

CAIRUS, H. F. O lugar dos clássicos hoje: o supercânone e seus desdobramentos no Brasil. In: VIEIRA, B. V. G; THAMOS, M. N (Orgs). Permanência clássica: visões contemporâneas da antiguidade greco-romana. São Paulo: Escrituras, 2011, p. 125-143.

CONTE, G. B; BARCHIESI, A. Imitação e arte alusiva. Modos e funções da Intertextualidade. In: CAVALLO, G. et al. O espaço literário da Roma Antiga. Trad. Daniel Peluci Carrara e Fernanda Messeder Moura. Belo Horizonte: Tessitura, 2010, p. 87-121. (Vol. I: A produção do texto)

DOLHNIKOFF, L. O paradigma nacional-popular da USP em literatura. Sibila, 2011. Disponível em: <http://sibila.com.br/cultura/o-paradigma-nacional-popular-da-usp-emliteratura/5012>. Acesso em 20 Jun. 2014.

ENZENSBERGER, H. M. A massa folhada do tempo: meditações sobre o anacronismo. In: Ziguezague: Ensaios. Trad. Marcos José Cunha. Rio de Janeiro: Imago, 2003, p. 9-23.

GENETTE, G. Palimpsests: la littérature au second degré. Paris: Seuil, 1982.

HORACE. Odes and epodes. Edited and Translated by Niall Rudd. Cambridge/London: Harvard University Press, 2004.

LUCIANO. Diálogos dos mortos. Trad. M. C. C. Dezotti. São Paulo: Hucitec, 1996. 
MORICONI, Í. Pós-modernismo e volta do sublime na poesia brasileira. In: PEDROSA, C; MATOS, C; NASCIMENTO, E. Poesia hoje. Rio de Janeiro: EdUFF, 1998, p. 11-26.

NISBET, R. G. M; HUBBARD, M. A commentary on Horace Odes, Book I. Oxford: Claredon Press, 2001.

NUNES, B. A recente poesia brasileira: expressão e forma. In: A clave do poético. São Paulo: Companhia das Letras, 2009, p. 158-173.

PAZ, O. A tradição do futuro. In: Os filhos do barro. Do romantismo à vanguarda. Trad. Olga Savary. Rio de Janeiro: Nova Fronteira, 1984, p. 17-35.

PEDROSA, C. Considerações anacrônicas: lirismo, subjetividade, resistência. In: CAMARGO, M. L. B; PEDROSA, C. (Orgs.) Poesia e contemporaneidade: leituras do presente. Chapecó: Argos, 2001, p. 7-23.

PESSOA, F. Poesia completa de Ricardo Reis. (Org.) SILVA, Manuela Parreira da. São Paulo: Cia das Letras, 2007.

SANTIAGO, S. A permanência do discurso da tradição no Modernismo. In: . Nas malhas da letra: Ensaios. São Paulo: Companhia das Letras, 1989, p. 94-121.

SARAIVA, F. R. S. Novíssimo dicionário latino-português. 10. ed. Rio de Janeiro: Garnier, 1993.

SECCHIN, A. C. Caminhos recentes da poesia brasileira. In: Poesia e desordem: escritos sobre poesia e alguma prosa. Rio de Janeiro: Topbooks, 1996, p. 93-110.

SIMON, I. M. Considerações sobre a poesia brasileira em fim de século. In: Novos Estudos CEBRAP, nº 55. São Paulo, Nov. 1999.

. Condenados à tradição: o que fizeram com a poesia brasileira. Revista Piauí, ${ }^{\circ} 61$, São Paulo, Out. 2011. Disponível em: < http://revistapiaui.estadao.com.br/edicao-61/aceleracao-docrescimento/condenados-a-tradicao>. Acesso em 18 Jun. 2014.

Artigo recebido em: 12.01 .2015

Artigo aceito em: 30.06.2015 